\title{
PRODUCTION OF ESTONIAN VOWELS BY FINNISH SPEAKERS
}

\author{
Einar Meister ${ }^{1,2}$ and Lya Meister ${ }^{2}$ \\ ${ }^{1}$ University of Eastern Finland and ${ }^{2}$ Tallinn University of \\ Technology
}

\begin{abstract}
In the study, we examined the production of Estonian vowel categories by second language (L2) speakers of Estonian (native language Finnish) and compared them to those of native Estonian (L1) speakers. The vowel systems of the two languages are very similar: all eight Finnish vowels have close counterparts in Estonian, though Estonian has one more vowel category. The vowels for acoustic analysis were extracted from the target words embedded in sentences read by both L1 and L2 informants. The results showed that using the native Finnish vowel patterns for the Estonian counterparts has been a successful strategy - due to phonetic similarity of the shared vowels in the two languages, the L2 vowels assimilate well to Finnish L1 vowel categories. The L2 learners have acquired proper tongue position for the new vowel category / $/$ / in tongue height and in front-back dimension, but deviate from the L1 speakers in use of the lip rounding gesture.
\end{abstract}

Keywords: Estonian, Finnish, L2, vowel production, acoustic analysis

DOI: https://doi.org/10.12697/jeful.2019.10.1.07

\section{Introduction}

Numerous studies have shown that novel second language (L2) contrasts are difficult to acquire; this issue typically results in deviant production of L2 segments, especially in the case of adult learners. Theoretical models of L2 phonological acquisition such as the Speech Learning Model (SLM) (Flege 1995), the Perceptual Assimilation Model (PAM) (Best 1995) and its extension, PAM-L2 (Best and Tyler 2007), and the Second Language Linguistic Perception model (L2LP) (Escudero 2005, 2009, and van Leussen and Escudero 2015) make predictions of how L2 sounds can be categorised based on the phonetic and phonological similarities and differences between the sounds in a learner's native language (L1) and L2. Basically, the models propose 
two possible scenarios: (1) assimilation with the L1 category will take place when a non-native sound is perceptually and acoustically identical or close to a native sound, and (2) new sound categories will be created for those L2 sounds that do not resemble any existing native category. The PAM-L2 model also foresees a third scenario for a non-native phone perceived as an uncategorised (non-speech) sound. Depending on the size of phoneme inventories in L1 and L2, various single-, twoand multiple-category assimilations may occur, resulting in different perceptual assimilation patterns (van Leussen and Escudero 2015, and Faris et al. 2016).

In this study, we explore the acoustic characteristics of Estonian vowels produced by L2 speakers of Estonian whose L1 is Finnish. Estonian and Finnish are closely related quantity languages, sharing the same eight vowels /i, y, e, ø, æ, a, o, u/, while Estonian has one additional vowel represented by the letter $<\tilde{0}>$. The shared vowels, phonetically, are almost identical and L2 study participants can successfully rely on their native vowel categories in both perception and production of the Estonian counterparts. Most of the shared vowels are identically represented in the orthography, only Finnish $<y>$ is represented by $<\ddot{u}>$ in Estonian. The ninth L2 vowel - mid-back unrounded / $/$ / - constitutes a new vowel category which might be challenging for the L 2 speakers with Finnish-language background.

Another important feature of the two languages is contrastive use of duration of vowels (and consonants) to distinguish lexical items or grammatical forms; however, there are several language-specific differences (to be discussed in the next chapter). Regardless of differences in the quantity systems, vowel quality in both languages is rather independent of durational variations and is not expected to affect acquisition of the new L2 vowel category.

In Section 2, we will present a comparison of Estonian and Finnish vowel systems and provide the hypotheses of the study. Then, in Section 3 (on methodology), we will describe the corpus of data, the participants, and the analysis methods. In Section 4, Results, we provide data on vowel formants produced both L1 and L2 subjects and finally, we will summarise the main findings of the study. 


\section{Estonian and Finnish vowel systems}

The Estonian vowel system includes nine vowels represented in the orthography as $<i$, ü, e, ö, ä, a, o, o, u $>$ and transcribed in the IPA alphabet as [i, y, e, ø, æ, a, $\gamma$, o, u] (Asu and Teras 2009). Based on their articulatory features, they are grouped into three height levels: close /i, ü, u/; mid /e, ö, õ, o/, open /ä, a/; and front /i, ü, e, ö, ä/ and back /a, o, o, u/ vowels whereas, in the case of the vowels / ̈u, u, ö, o/, lip rounding is involved (Table 1). The unrounded back vowel /õ/ shows larger variations, that is, extending from mid to high areas and, depending on the speaker's dialectal background, can be produced as a midback vowel [ $\gamma$ ], a close-back vowel [w], or a mid-central vowel [९] (Eek and Meister 1994, 1999).

The Finnish vowel system has eight vowels /i, y, e, ö, ä, a, o, u/, which are phonetically roughly identical to their Estonian counterparts.

Table 1. Articulatory features of Estonian and Finnish vowels.

\begin{tabular}{|c|c|c|c|c|c|}
\hline & \multicolumn{2}{|c|}{ Front } & \multicolumn{2}{|c|}{ Back } & \\
\hline & Unrounded & Rounded & Unrounded & Rounded & \\
\hline \multirow{3}{*}{ 莕 } & $/ \mathrm{i} /[\mathrm{i}]$ & $/ \ddot{\mathrm{u}} /[\mathrm{y}]$ & & $/ \mathrm{u} /[\mathrm{u}]$ & High \\
\hline & $/ \mathrm{e} /[\mathrm{e}]$ & /Ö/ [Ø] & $/ \tilde{\mathbf{o}} /[\boldsymbol{\gamma}]$ & $/ \mathrm{o} /[\mathrm{o}]$ & Mid \\
\hline & $/ \ddot{a} /[æ]$ & & $/ a /[a]$ & & Low \\
\hline \multirow{3}{*}{ 怘 } & /i/ [i] & $/ \mathrm{y} /[\mathrm{y}]$ & & $/ \mathrm{u} /[\mathrm{u}]$ & High \\
\hline & $/ \mathrm{e} /[\mathrm{e}]$ & /Ö/ [ø] & & $/ \mathrm{o} /[\mathrm{o}]$ & Mid \\
\hline & /ä/ [æ] & & $/ \mathrm{a} /[\mathrm{a}]$ & & Low \\
\hline
\end{tabular}

Estonian features a ternary quantity contrast - referred to as short (Q1), long (Q2), and overlong (Q3) quantity degrees - realised by a complex interaction of durational relationships and tonal cues in a foot (a disyllabic sequence consisting of the stressed and the following unstressed syllable, for example, Q1 sada /sata/ 'hundred', nom.sg.; Q2 saada /saata/ 'to send', sg.imperat.; Q3 saada /saa:ta/ "to get'; Q1 kade /kate/ 'envious', nom.sg.; Q2 kate /katte/ 'cover', nom.sg.; Q3 katte/kat:te/ 'cover', gen.sg. (e.g., Lehiste 1997, 2003, Eek and Meister 
1997, 2003, and Asu et al. 2016). It is important to note that Q2 and Q3 contrasts are revealed in the orthography in the case of plosives only.

In Finnish, the binary quantity contrast is segmental and fully revealed in the orthography, that is, phonologically long (double) segments are represented by double characters, for example, tuli /tuli/ or CVCV 'fire', tuuli /tuuli/ or CVVCV 'wind', tulli /tulli/ or CVCCV 'customs' (for more details see Suomi, Toivanen and Ylitalo 2008). In Finnish, in contrast to Estonian, vowel quantity opposition is also possible in unstressed syllables.

In both languages, a short versus long/overlong contrast manifested in the orthography does not mean that qualitatively similar segments in different quantities are separate phonemes; instead, they are considered as sequences of identical phonemes (for various interpretations see Suomi et al. 2008, for Finnish, and Eek 2008, for Estonian). Phonetic evidence for Estonian supporting the above interpretation is based on the analysis of vowel quality in distinctive quantity degrees showing that, in read speech, quantity-dependent quality variations of stressed vowels are rather minor for short and long vowels to be considered separate phonemes (Eek and Meister 1998). A comparative analysis of durational patterns in Finnish and Estonian is presented in Suomi et al. (2012); also, microdurational variations are reported to affect vowel category perception in Estonian and Finnish (Meister and Werner 2009); however, durational variations are not expected to influence the acquisition of L2 vowel categories. The formant values of Estonian vowels have been reported in several studies, including those investigating vowels in isolated production (e.g., Liiv and Remmel 1970, and Eek and Meister 1994), in reading (e.g., Eek and Meister 1998, and Meister 2011) and in spontaneous speech (Lippus et al. 2013; for an overview, see Asu et al. 2016: 29-47). Vowels in stressed syllables of read speech tend to be more central compared to isolated vowels, and are even more centralised in spontaneous speech; quantity-related quality variations exhibit a similar tendency and vowels in Q1 are more centralised than vowels in Q2 and Q3 (cf. Eek and Meister 1998, and Lippus et al. 2013). Vowels in unstressed syllables are qualitatively reduced when compared to stressed vowels, especially unstressed vowels in Q3 feet.

According to the seminal work by Wiik (1965), the quality differences between Finnish short and long vowels are rather minor and 
exhibit similar trends to those of Estonian vowels: long vowels are more peripheral than their short counterparts in both stressed and unstressed syllables, and short vowels in unstressed syllables are placed more centrally compared to short vowels in stressed positions.

To compare the vowel systems of the two languages, Figure 1 presents the vowel charts based on data by Meister (2011) and Kuronen (2000) for Estonian (left) and Finnish (right), respectively:
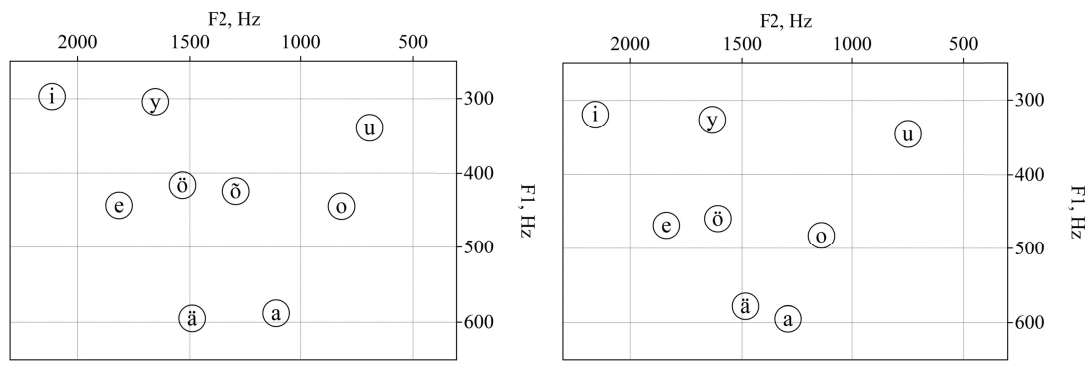

Figure 1. Estonian (left) and Finnish (right) vowel charts based on the formant data by Meister (2011) (read speech, 5 male speakers), and Kuronen (2000) (read speech, 4 male speakers), respectively.

Also, the perceptual vowel charts for Finnish and Estonian (Raimo et al. 2002) demonstrate high similarity of vowel categories in the case of most shared vowels in the two languages (Figure 2). The charts represent the native perceptual vowel category spaces and boundaries averaged over multiple native subjects. The perceptual space of / $/$ mainly overlaps with the spaces of Finnish /ö/ (42\%) and, to a lesser extent, with /u/ $(28 \%), / \mathrm{y} /(15 \%), / 0 /(9 \%)$, and /a/ (6\%) spaces. This looks different from Wiik's (1986) results reporting the following overlapping proportions of the Estonian /õ/ with Finnish native vowels: $40 \%$ of $/ \mathrm{u} /, 30 \%$ of $/ \mathrm{o} /, 20 \%$ of $/ \ddot{\mathrm{o}} /, 6 \%$ of $/ \mathrm{ü} /$, and $4 \%$ of $/ \mathrm{a} /$. 

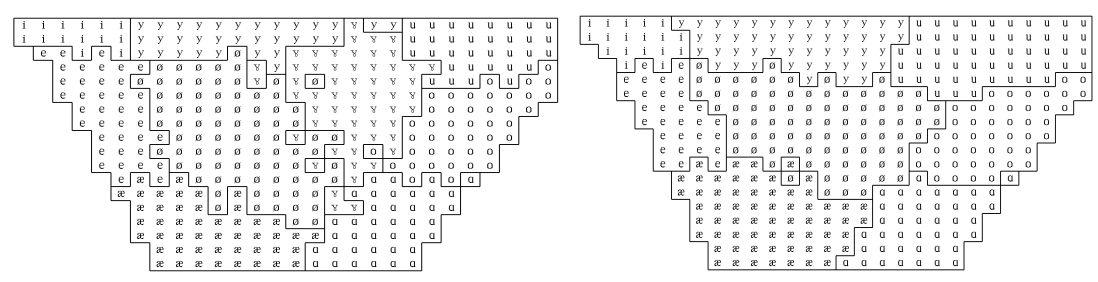

Figure 2. Estonian (left) and Finnish (right) perceptual vowel charts (Raimo et al. 2002). The charts represent the preliminary results of the study; the number of subjects taking the online listening experiment was not reported. According to Raimo (personal communication in 2002), the fuzzier category boundaries of the Estonian chart compared to Finnish are caused by the smaller number of Estonian participants.

Earlier studies on non-native production of Estonian vowels were largely limited to learners of Estonian with Russian (Meister 2011), Japanese (Nemoto et al. 2015), and Spanish (Leppik and Lippus 2014) language background. In all these languages, the number of vowel categories is smaller than in Estonian (Russian - 6, Japanese and Spanish -5 ) and, as the studies showed, the L2 learners were successful in the production of these L 2 vowels; that is, they assimilated their speech production to their native counterparts and exhibited deviating (native language-specific) production of the new vowel categories.

For L2 speakers with Finnish language background there is only one new vowel category to acquire - the mid back unrounded /õ/. In the perceptual space it would mean the adjustment mainly of the category boundaries of /o/ and /o/ in the F2 dimension in order to accommodate the new category between them (cf. charts in figures 1 and 2). Articulatorily it would mean acquiring the new tongue position in the frontback dimension, and the unrounding of the lips. According to L2LP, the shared vowels represent the SIMILAR scenario for L2 subjects since the existing Finnish vowel categories match one-to-one with the L2 counterparts. The acquisition of the L2 vowel /o/ represents the SUBSET scenario with multiple category assimilation as it can be perceived as more than one Finnish vowel (see Wiik 1986; data above) and thus its acquisition might be hindered. 
We hypothesise that L2 speakers with Finnish language background:

(1) will rely on their native vowel categories and produce the Estonian counterparts close to native speakers since due to phonetic similarity of the shared vowels in the two languages, the L2 vowels assimilate well to their $\mathrm{L} 1$ categories,

(2) will face difficulties in the acquisition of the new vowel category due to assimilation to native $/ 0 / \mathrm{or} / \mathrm{o} /$, resulting in deviant production of Estonian /õ/.

\section{Method}

\subsection{Material and informants}

For the study, speech material from the Estonian Foreign Accent Corpus (Meister and Meister 2012, 2015) was used. The L1 cohort comprises 20 native Estonian speakers ( 7 male, 13 female, ages 18-70, median age 29) mostly from North Estonia. All L1 study participants produced standard Estonian pronunciation; they were recorded in a sound-treated room at Tallinn University of Technology using highquality recording equipment (a laptop computer with Adobe Audition software, a USB interface with microphone preamplifiers, and two condenser microphones - a close-talking and a desktop microphone; sampling frequency $44.1 \mathrm{kHz}, 16$ bit, wav format).

The L2 group was comprised of 20 female and 10 male native speakers of Finnish (female ages ranged from 19-62, median age 24.5; male ages were $22-49$, median age 36 ) recruited from universities in Helsinki, Turku and Oulu, and, as well, several in Tallinn. The participants had studied Estonian for 1-5 years, starting at the age of 18-47 (median 22.5); in self-assessment, they reported their L2 proficiency as follows: "elementary" - 9, "intermediate" - 15, "advanced" - 4, "proficient" -2 speakers. The L2 subjects were recorded at the universities in Finland and at Tallinn University of Technology, using the same recording equipment as elaborated above.

All study participants read the same set of 140 sentences; for the current study, a subset of 72 sentences was used, including 27 sentences where segmentally identical disyllabic target words represented the vocalic quantity contrast (Q1: CVCV, Q2: CVVCV, Q3: CVV:CV). For example: 
Kämping nimega R̃̃mu suletakse talveks. [The camping ground called Rõmu will be closed for the winter.]

Lapse rõ̃omu pärast olen valmis paljuks. [For a child's joy I could do a lot.]

Tundsin rohkem rõ̃omu kui kurbust. [I felt more joy than sadness.]

The recordings were manually segmented using Praat (Boersma and Weeninck 2018) at word and phonemic levels.

\subsection{Formant analysis}

Only the stressed-syllable vowels (V1) were allocated for the acoustic analysis; in total, there were 197 vowels per speaker, distributed as follows: /a/ - 49, /e/ - 21, /i/ - 18, /o/ - 38, /u/ - 22, /õ/ - 9, /ä/ - 19, $/ \ddot{o} /-9, / \ddot{\mathrm{u}} /-12$. Formant analysis was performed with a customised Praat script exploiting Burg method, with standard settings (max number of formants: 5, max formant frequency: $5000 \mathrm{~Hz}$ for males and 5500 $\mathrm{Hz}$ for females, window length: $25 \mathrm{~ms}$, time step: $10 \mathrm{~ms}$, pre-emphasis from: $50 \mathrm{~Hz}$ ). The values of the formants F1-F3 were measured around the midpoint of vowels (in a section of $20 \%$ of vowel duration) followed by data cleaning to exclude obvious measurement errors. For each speaker, average formant values for each vowel category were pooled.

\section{Results}

The average F1-F3 frequencies for L1 and L2 speaker groups are reported in Table 2 and the corresponding vowel charts are presented in Figures 3 and 4.

To compare the production of the two subject groups, ANOVA and Tukey HSD tests were performed using RStudio (RStudio Team 2015). Both male and female L2 subjects produced the shared vowels very close to the L1 subjects and reached native-like production in terms of tongue height (F1) and front-back dimension (F2) of the new vowel category /ô/; see Figure 3. In male subjects, significant differences were only found in $/ \mathrm{u}$ ( (for both F1 and F2, $p<.001$ ), which was produced by the L2 males higher and more backward, and in /a/ (F2: $p<.001)$ which had more fronted location in L2 speech. In female subjects, more L1-L2 
differences were found in both F1 and F2 dimensions: all mid vowels and the open vowel /a/ were produced slightly lower (F1: $p<.01$ for $/ \ddot{\mathrm{o}} /$, $p<.001$ for others) and the vowels $/ \mathrm{i}, \mathrm{u}, \mathrm{u}, \mathrm{e}, \mathrm{a} /$ were produced more backward (F2: $p<.001)$ by the L2 females.

In respect of F3 (correlated with the lip-rounding gesture), both male and female L2 production deviated from L1 in the case of $/ \tilde{\mathrm{o}} /(p<.001)$; in addition, $\mathrm{F} 3$ differences were found in low vowels $(/ \mathrm{a} /: p<.01$, /ä/: $p<.001$ ) of L2 females' speech. In the F1 versus F3 acoustic space, the L2 /õ/ was located close to the rounded vowels /ö/ and /o/, while in L1 speech, rounded and unrounded vowels formed clearly separated clusters (Figure 4).

Table 2. Average formant frequencies and standard deviations (in parentheses) of stressed Estonian vowels produced by L1 and 12 subjects.

\begin{tabular}{|c|c|c|c|c|c|c|c|}
\hline \multirow{2}{*}{ Gender } & \multirow{2}{*}{ Vowel } & \multicolumn{3}{|c|}{ L1 } & \multicolumn{3}{|c|}{ L2 } \\
\hline & & $\mathrm{F} 1, \mathrm{~Hz}$ & $\mathrm{~F} 2, \mathrm{~Hz}$ & $\mathrm{~F} 3, \mathrm{~Hz}$ & $\mathrm{~F} 1, \mathrm{~Hz}$ & $\mathrm{~F} 2, \mathrm{~Hz}$ & $\mathrm{~F} 3, \mathrm{~Hz}$ \\
\hline \multirow{9}{*}{$\frac{0}{\pi}$} & $\mathrm{a}$ & $586(61)$ & $1111(105)$ & 2437 (267) & 599 (69) & $1160(127)$ & $2392(224)$ \\
\hline & $\mathrm{e}$ & $446(51)$ & $1760(169)$ & $2496(164)$ & 448 (54) & $1782(163)$ & $2447(241)$ \\
\hline & $\mathrm{i}$ & 314 (37) & $2084(122)$ & $2735(220)$ & $313(42)$ & $2052(267)$ & $2695(283)$ \\
\hline & o & $474(38)$ & 925 (154) & $2252(205)$ & $461(48)$ & 906 (119) & 2225 (278) \\
\hline & $\mathrm{u}$ & $378(43)$ & 885 (185) & $2304(225)$ & 339 (39) & $781(155)$ & $2271(259)$ \\
\hline & $\tilde{o}$ & $439(33)$ & $1248(94)$ & 2438 (198) & 434 (69) & 1254 (159) & $2225(176)$ \\
\hline & $\ddot{a}$ & $578(70)$ & $1507(145)$ & 2353 (187) & $600(73)$ & $1508(144)$ & $2336(185)$ \\
\hline & $\ddot{o}$ & $421(30)$ & $1536(71)$ & 2251 (107) & 435 (41) & $1543(127)$ & $2298(188)$ \\
\hline & $\ddot{\mathrm{u}}$ & $317(29)$ & $1667(92)$ & $2185(110)$ & 305 (38) & $1590(217)$ & $2175(218)$ \\
\hline \multirow{9}{*}{$\begin{array}{l}\frac{0}{\tilde{\Xi}} \\
\text { है } \\
\text { II }\end{array}$} & $\mathrm{a}$ & $700(103)$ & $1362(215)$ & $2730(311)$ & 736 (137) & $1356(140)$ & $2674(281)$ \\
\hline & e & $523(72)$ & $2187(252)$ & 2952 (237) & $561(82)$ & $2098(248)$ & $2882(255)$ \\
\hline & $\mathrm{i}$ & $380(59)$ & $2618(168)$ & 3244 (257) & 389 (67) & $2490(271)$ & $3182(292)$ \\
\hline & o & 509 (63) & $1046(184)$ & 2721 (299) & $541(98)$ & $1066(167)$ & $2684(277)$ \\
\hline & $\mathrm{u}$ & $408(66)$ & $1001(219)$ & 2748 (293) & 393 (56) & $878(261)$ & $2792(276)$ \\
\hline & $\tilde{o}$ & $474(56)$ & $1447(152)$ & $2908(258)$ & $537(102)$ & $1438(254)$ & $2668(231)$ \\
\hline & ä & $762(103)$ & $1803(175)$ & $2814(257)$ & 769 (110) & $1710(196)$ & $2658(281)$ \\
\hline & $\ddot{0}$ & 482 (39) & 1853 (119) & 2699 (189) & 540 (89) & $1781(161)$ & $2733(181)$ \\
\hline & $\ddot{\mathrm{u}}$ & $390(62)$ & 1903 (207) & 2654 (264) & $375(58)$ & 1789 & $2605(204)$ \\
\hline
\end{tabular}



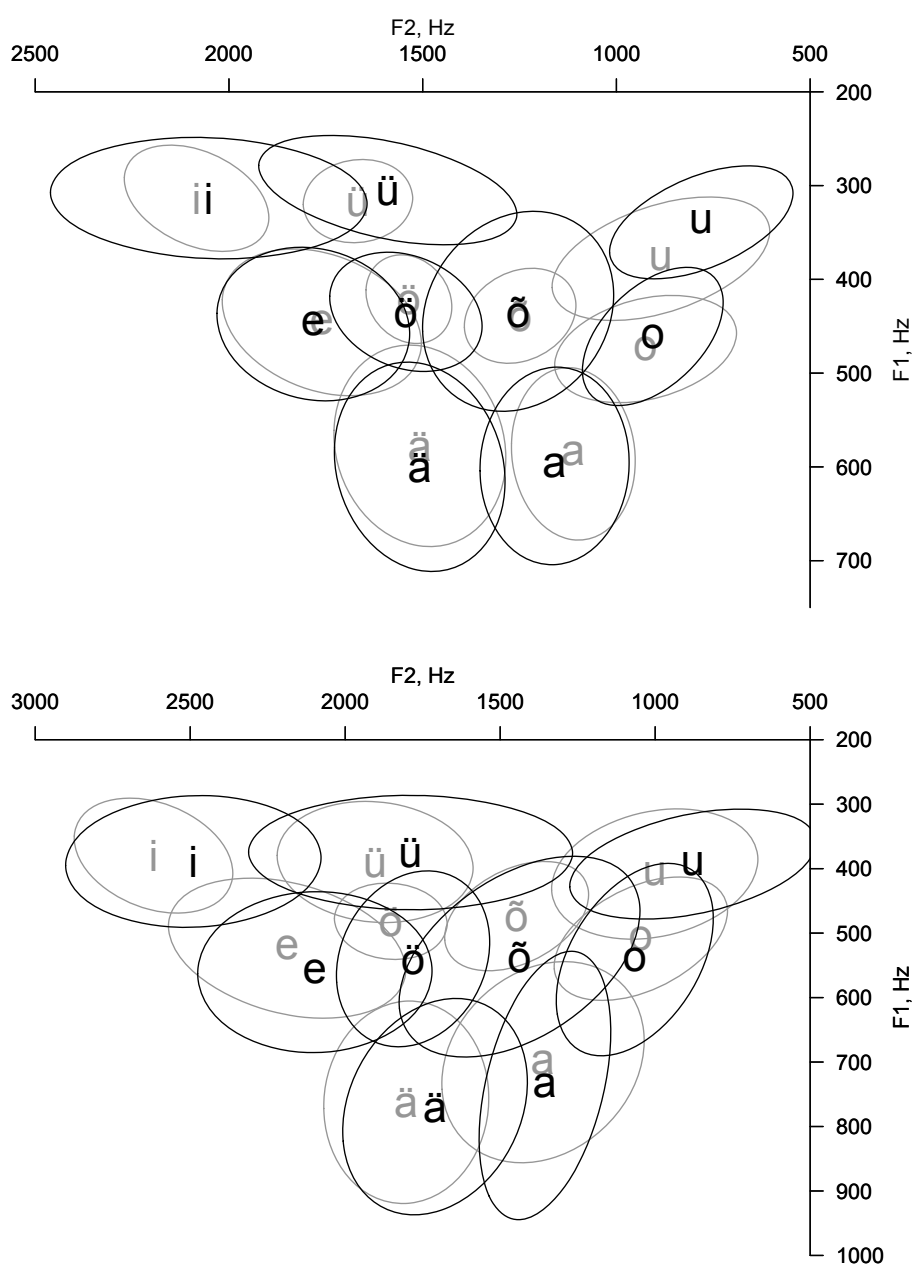

Figure 3. Male (top) and female (bottom) stressed vowels in the acoustic space of F1 versus F2 produced by L1 (grey) and L2 (black) subjects. The ellipses correspond to \pm 1 standard deviation. 

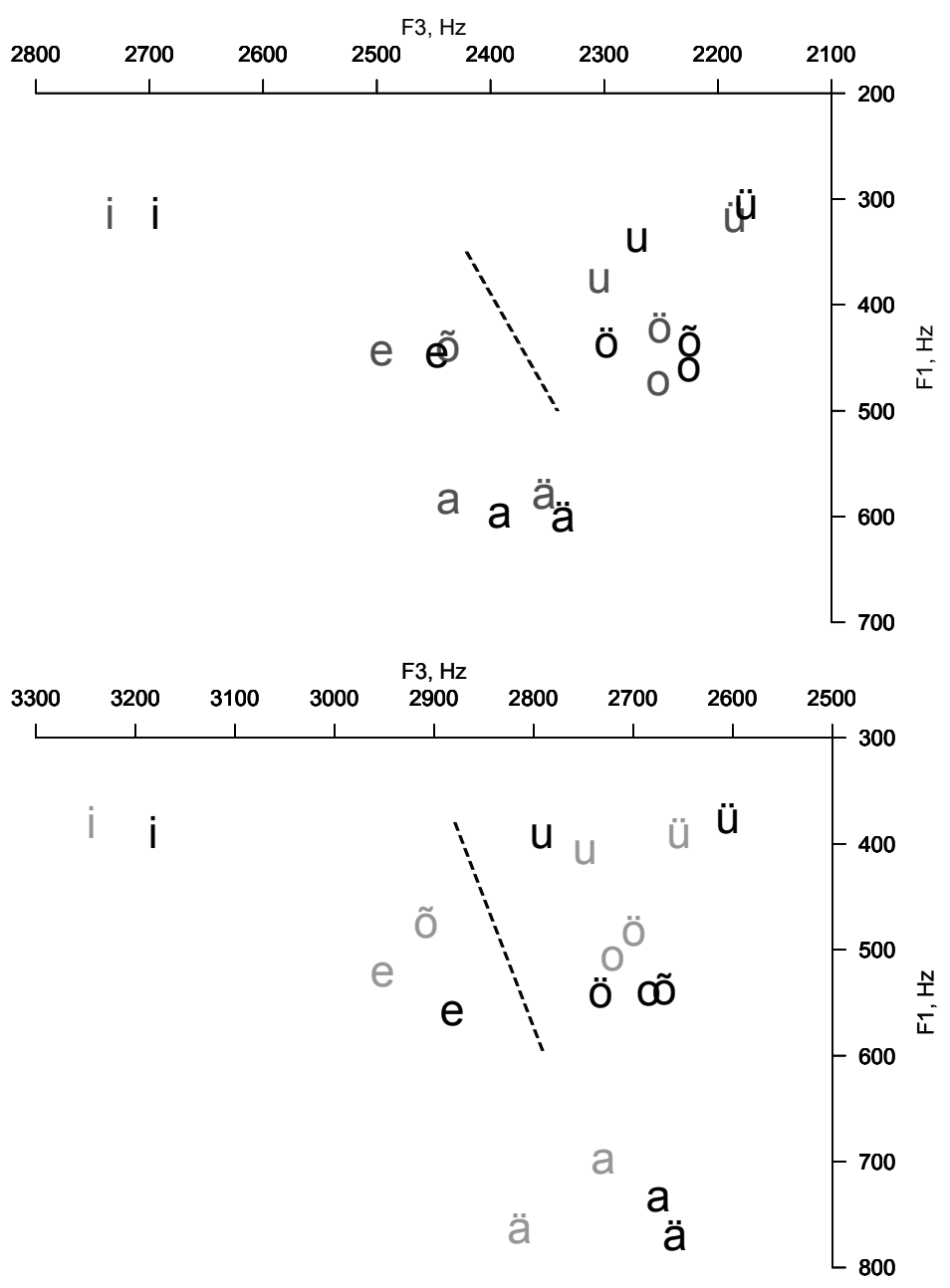

Figure 4. Male (top) and female (bottom) stressed vowels in the acoustic space of F1 versus F3 produced by of L1 (grey) and L2 (black) subjects. The dashed line separates close and mid rounded (right) and unrounded (left) vowels. Notice the location of L2 /õ/-vowel. 


\section{Conclusion}

As expected, the L2 subjects successfully applied their native Finnish vowel patterns for the production of the Estonian counterparts and achieved native-like production of the shared L2 vowels. In the acquisition of the new vowel category /õ/ the L2 subjects were less successful - they produced it in a native-like way in terms of F1 (tongue height) and F2 (front-back dimension), however, deviations from the L1 subjects in $\mathrm{F} 3$ values suggest that they have not acquired proper articulatory gestures related to lip-rounding, that is, they do not adequately unround their lips during the production of /õ/.

\section{Acknowledgements}

This research has been supported by the European Regional Development Fund (Centre of Excellence in Estonian Studies - CEES). All participants of the study are gratefully acknowledged.

\section{Addresses:}

Einar Meister

School of Humanities

University of Eastern Finland

PO Box 111, 80101 Joensuu, Finland

E-mail: einar.meister@uef.fi

Department of Software Science

Tallinn University of Technology

Akadeemia tee $15 \mathrm{a}$

12618 Tallinn, Estonia

E-mail: einar.meister@ttu.ee

Lya Meister

Department of Software Science

Tallinn University of Technology

Akadeemia tee $15 \mathrm{a}$

12618 Tallinn, Estonia

E-mail: lya.meister@ttu.ee 


\section{References}

Asu, Eva Liina and Pire Teras (2009) "Illustrations of the IPA: Estonian". Journal of the International Phonetic Association 39, 3, 367-372.

Best, Catherine T. (1995) "A direct realist perspective on cross-language speech perception”. In Winifred Strange, ed. Speech perception and linguistic experience: issues in cross-language research, 171-204. Timonium, MD: York Press.

Best, Catherine T. and Michael D. Tyler (2007) "Nonnative and second-language speech perception: commonalities and complementarities". In Murray J. Munro and OckeSchwen Bohn, eds. Language experience in second language speech learning: in honor of James Emil Flege, 13-34. Amsterdam: John Benjamins.

Boersma, Paul and David Weenink (2019) Praat: doing phonetics by computer [Computer program]. Version 6.0.48. Available online at $<$ http://www.praat.org/>. Accessed on 18.02.2018.

Eek, Arvo (2008) Eesti keele foneetika I. Tallinna Tehnikaülikool, Küberneetika Instituut. Tallinn: TTÜ Tallinna Tehnikaülikooli Kirjastus.

Eek, Arvo and Einar Meister (1994) "Acoustics and perception of Estonian vowel types". In Mats Dufberg and Olle Engstrand, eds. PERILUS XVIII: Experiments in speech processes, 55-90. Stockholm: Stockholm University.

Eek, Arvo and Einar Meister (1997) "Simple perception experiments on Estonian word prosody". In Ilse Lehiste and Jaan Ross, eds. Estonian prosody: papers from a symposium, 71-99. Tallinn: Institute of Estonian Language.

Eek, Arvo and Einar Meister (1998) "Quality of standard Estonian vowels in stressed and unstressed syllables in the feet in three distinctive quantity degrees". Linguistica Uralica 34, 3, 226-233.

Eek, Arvo and Einar Meister (1999) "Estonian speech in the BABEL multi-language database: phonetic-phonological problems revealed in the text corpus". In Osamu Fujimura, Brian D. Joseph, and Bohumil Palek, eds. Proceedings of the Fourth Linguistics and Phonetics Conference (LP'98) 2, 529-546. Prague: The Karolinum Press.

Eek, Arvo and Einar Meister (2003) "Foneetilisi katseid ja arutlusi kvantiteedi alalt (I). Häälikukestusi muutvad kontekstid ja välde”. Keel ja Kirjandus 46, 11-12, 815837, 904-918.

Elvin, Jaydene, Paola Escudero, and Polina Vasiliev (2014). "Spanish is better than English for discriminating Portuguese vowels: acoustic similarity versus vowel inventory size". Frontiers in Psychology 5, 1188, 1-8.

Escudero, Paola (2005) Linguistic perception and second language acquisition. Explaining the attainment of optimal phonological categorization. $\mathrm{PhD}$ thesis, Utrecht University.

Escudero, Paola (2009) "Linguistic perception of 'similar' L2 sounds". In Paul Boersma and Silke Hamann, eds. Phonology in perception, 151-190. Mouton de Gruyter.

Escudero, Paola and Paul Boersma (2002) "The subset problem in L2 perceptual development: multiple-category assimilation by Dutch learners of Spanish". In Barbora Skarabela, Sarah Fish, and Anna H.-J. Do, eds. Proceedings of the 26th Annual Boston University Conference on Language Development, 208-219. Cascadilla Press. 
Escudero, Paola, Bianca Sisinni, and Mirko Grimaldi (2014) "The effect of vowel inventory and acoustic properties in Salento Italian learners of Southern British English vowels". Journal of the Acoustical Society of America 135, 1577-1584.

Escudero, Paola and Daniel Williams (2012) "Native dialect influences second-language vowel perception: Peruvian versus Iberian Spanish learners of Dutch". Journal of the Acoustical Society of America 131, EL406-EL412.

Faris, Mona M., Catherine T. Best, and Michael D. Tyler (2016) "An examination of the different ways that non-native phones may be perceptually assimilated as uncategorized". Journal of the Acoustical Society of America 139, 1, EL1-5.

Flege, James E. (1995) "Second language speech learning: theory, findings, and problems". In Winifred Strange, ed. Speech perception and linguistic experience: issues in cross-language research, 233-277. Timonium, MD: York Press.

Kuronen, Mikko (2000) Vokaluttalets akustik I sverigesvenska, finlandssvenska och finska. Jyväskylä: Jyväskylä University Printing House.

Lehiste, Ilse (1997) "Search for phonetic correlates in Estonian prosody". In Ilse Lehiste and Jaan Ross, eds. Estonian prosody: papers from a symposium, 11-35. Tallinn: Institute of Estonian Language.

Lehiste, Ilse (2003) "Prosodic change in progress: from quantity language to accent language". In Paula Fikkert and Haike Jakobs, eds. Development in prosodic systems. Studies in generative grammar, 47-65. Berlin and New York: Mouton de Gruyter.

Leppik, Katrin and Pärtel Lippus (2014) "A comparative study of Estonian and Spanish vowels in L1 and L2 production". In Katri Jähi and Laura Taimi, eds. XXVIII Fonetiikan päivät. Turku 25.-26. lokakuuta 2013. Konferenssijulkaisu, 19-26. Turku: Turun yliopisto.

Liiv, Georg and Mart Remmel (1970) "On acoustic distinction in the Estonian vowel system”. Soviet Fenno-Ugric Studies 1, 7-23.

Lippus, Pärtel, Eva Liina Asu, Pire Teras, and Tuuli Tuisk (2013) “Quantity-related variation of duration, pitch and vowel quality in spontaneous Estonian". Journal of Phonetics 41, 1, 17-28.

Meister, Lya (2011) Eesti vokaali- ja kestuskategooriad vene emakeelega keelejuhtide tajus ja häälduses. Eksperimentaalfoneetiline uurimus. Doktoritöö, Tartu Ülikool, eesti ja üldkeeleteaduse instituut. Tartu: Tartu Ülikooli Kirjastus.

Meister, Einar and Lya Meister (2012) "Aktsendikorpus ja võõrkeele aktsendi uurimine". Keel ja Kirjandus 55, 8-9, 696-714.

Meister, Einar and Lya Meister (2015) "Development and use of the Estonian L2 corpus”. In Jürgen Trouvain, Frank Zimmerer, Mária Gósy, and Anne Bonneau, eds. Book of extended abstracts. Workshop on phonetic learner corpora, 45-47. Satellite workshop of the 18th International Congress of Phonetic Sciences.

Meister, Einar and Stefan Werner (2009) "Duration affects vowel perception in Estonian and Finnish". Linguistica Uralica 45, 3, 161-177.

Nemoto, Rena, Einar Meister, and Lya Meister (2015) "Production of Estonian vowels by Japanese subjects". Proceedings of the 18th International Congress of Phonetic Sciences (ICPhS 2015), 1-5. 
Raimo, Ilkka, Janne Savela, and Olli Aaltonen (2002) “The Turku vowel test”. In Petri Korhonen, ed. Fonetiikan Päivät 2002. The Phonetics Symposium 2002, 45-52. Espoo: Teknillinen korkeakoulu.

RStudio Team (2015). RStudio: integrated development for R. RStudio, Inc., Boston, MA. Available online at $<$ http://www.rstudio.com/>. Accessed on 14.01.2019.

Suomi, Kari, Juhani Toivainen, and Riikka Ylitalo (2008) Finnish sound structure: phonetics, phonology, phonotactics and prosody. Oulu: University of Oulu.

van Leussen, Jan-Willem and Paola Escudero (2015) "Learning to perceive and recognize a second language: the L2LP model revised". Frontiers in Psychology $6,1000,1-12$.

Wiik, Kalevi (1965) Finnish and English vowels: a comparison with special reference to the learning problems met by native speakers of Finnish learning English. (Annales Universitatis Turkuensis, B94.) Turku: Turun Yliopisto.

Wiik, Kalevi (1986) Viron o. (Turun yliopiston suomalaisen ja yleisen kielitieteen laitoksen julkaisuja, 30.) Turku.

\section{Kokkuvõte. Einar Meister ja Lya Meister: Eesti vokaalid soome ema-} keelega keelejuhtide häälduses. Artiklis uuriti soome emakeelega keelejuhtide eesti vokaalide hääldust ja võrreldi seda eesti emakeelega keelejuhtide hääldusega. Eesti ja soome vokaalisüsteemid on väga sarnased - kõigil soome vokaalidel on eesti keeles foneetiliselt lähedane vaste. Eesti keeles on lisaks veel üks vokaalikategooria, s.o ümardamata keskkõrge tagavokaal /õ/. Uuringus kasutati eesti ja soome emakeelega keelejuhtide loetud samu lauseid, vokaalide akustiliseks analüüsiks eraldati neist rõhulised vokaalid. Kõigi vokaalide puhul leiti kolme formandi sagedused, millest esimene (F1) on seotud keele kõrgusega, teine (F2) keele ees-tagapoolsusega ja kolmas (F3) huulte ümardatusega. Tulemused näitasid, et (1) tänu soome vokaalide foneetilisele sarnasusele vastavate eesti vokaalidega oli soome emakeelega kõnelejate eesti vokaalide hääldus lähedane eesti emakeelega keelejuhtidele; (2) on omandatud küll /ô/-vokaali hääldusasend nii keele kõrguse (F1) kui ka ees-tagapoolsuse (F2) teljel, kuid F3 väärtuste põhjal paigutub soomlaste hääldatud /õ/ ümarate vokaalide rühma.

Märksõnad: eesti keel, soome keel, L2, vokaalide hääldus, akustiline analüüs 